DOI 10.14746/ssp.2018.1.2

Jolanta Eliza ŻóıTowSKA

\title{
Układy wielkościowe największych ośrodków miejskich w państwach położonych na pomoście baltycko-czarnomorskim
}

Streszczenie: Zamierzeniem badawczym opracowania było porównanie rozkładu wielkościowego ośrodków miejskich w dwunastu państwach: Białorusi, Bułgarii, Republice Czeskiej, Estonii, Litwie, Łotwie, Mołdawii, Polsce, Rumunii, Słowacji, na Ukrainie i Węgrzech.

W celu wyjaśnienia postawionego problemu poznawczego wykorzystano dwie metody badawcze: tzw. regułę kolejności i wielkości G. K. Zipfa oraz analizę stopnia koncentracji M. O. Lorentza. Przed podjęciem zasadniczego tematu przedstawiono problematykę rozwoju demograficznego miast stołecznych w wybranych państwach w pięciu przekrojach czasowych (w latach: 1900, 1930, 1960, 2000 i około 2015 r.). Następnie na podstawie przyjętej metody przeprowadzono skwantyfikowaną ocenę roli największego miasta, jak i zależności wielkościowych, jakie występują między nim a pozostałymi analizowanymi jednostkami osadniczymi. Wydzielono kraje odznaczające się monocentryzmem i policentryzmem. Ostatecznie wyniki analizy statystycznej ujawniły przydatność zastosowanej metody do badań nad problematyką odniesioną do rozmieszczenia i wielkości różnych typów jednostek osadniczych na dowolnie wybranym terytorium.

Słowa kluczowe: demografia osadnictwa, miasta, stolice, pomost bałtycko-czarnomorski, reguła Z. K. Zipfa, koncentracja według M. O. Lorentza

$\mathbf{Z}$ adaniem niniejszego artykułu jest przypomnienie tzw. reguły wielkości i kolejności miast. Metoda ta została zaprezentowana polskim czytelnikom kilkadziesiąt lat temu, a następnie zapomniano o niej i pomimo przydatności nie była już przez geografów wykorzystywana. Zastosowanie jej do badań nad osadnictwem miejskim może być jednak przydatne tak ze względów metodycznych, jak i aplikacyjnych. Wydaje się więc celowe zaprezentowanie, a następnie zweryfikowanie jej wartości praktycznej przy analizie i ocenie stopnia koncentracji osadnictwa wielkomiejskiego.

Reguła kolejności i wielkości w badaniach osadnictwa miejskiego została jako matematyczne uogólnienie stanu równowagi pomiędzy siłami 
koncentracji i dekoncentracji na określonym terytorium zaprezentowana w pracach G. K. Zipfa (1946, s. 627-650; 1949) ${ }^{1}$. Zgodnie z założeniami tej metody, miasta wybranego obszaru szeregujemy od największego do najmniejszego i największe miasto otrzymuje rangę $\mathrm{nr} 1$, następne $\mathrm{nr} 2$, zaś kolejne zajmują coraz niższą pozycję - tworząc określony rozkład wielkościowy. Powstaje przejrzysty stosunek między rangą miasta a liczbą jego ludności. Teoretyczny rozkład wielkościowy miast w regule kolejności i wielkości G. K. Zipfa odpowiada regularnej krzywej zbliżającej się asymptotycznie, na wykresie do osi odciętej (x). Istnieje sprawdzalny stosunek między wielkością a kolejnością. Weryfikację empiryczną reguły kolejności i wielkości przeprowadził Ch. T. Stewart jr. (1958), który przebadał liczbę ludności pięciu największych miast w 72 państwach świata. Pomimo, że nie było pełnej zgodności między założeniami teoretycznymi G. K. Zipfa a układami rzeczywistymi, reguła kolejności i wielkości znalazła szerokie zastosowanie w badaniach nad osadnictwem miejskim. Czytelnikom polskim, metoda ta, została zaprezentowana przez K. Dziewońskiego (1963), a następnie wykorzystana empirycznie w artykule P. Eberhardta i S. Heřmana (1975) oraz przez J. E. Żółtowską $(2000,2016)^{2}$.

W niniejszym opracowaniu reguła kolejności i wielkości G. K. Zipfa zostanie wykorzystana do określenia relacji, jakie zachodzą między ośrodkami stołecznymi a pozostałymi dużymi ośrodkami miejskimi. Przedstawioną metodę postanowiono zastosować do wyjaśnienia rozkładu wielkościowego największych miast w wybranych państwach Europy Środkowo-Wschodniej. Do analizy empirycznej przyjęto 12 państw położonych na tzw. pomoście bałtycko-czarnomorskim, a mianowicie: Białoruś, Bułgarię, Republikę Czeską, Estonię, Litwę, Łotwę, Mołdawię, Polskę, Rumunię, Słowację, Ukrainę i Węgry. Najbardziej na północ położona jest Estonia, usytuowana nad Zatoką Fińską, zaś na krańcu południowym leży Bułgaria. Zaliczenie tych właśnie państw, do w ten

1 Stopień koncentracji przestrzennej określany jako tzw. metoda kolejności i wielkości po raz pierwszy został sformułowany przez F. Auerbacha (1912). W latach 20. i 30. XX wieku nadano wspomnianej metodzie postać bardziej sformalizowaną matematycznie. Wszechstronnie rozwinął ją i spopularyzował ją G. K. Zipf.

2 Zagadnieniom powyższym poświęcono także rozdziały „Metody związane z badaniem zjawiska koncentracji przestrzennej osadnictwa” i „Metody związane z zastosowaniem grawitacji i potencjału” w książce Metodyka geografii osadnictwa. Wybrane modele i narzędzia badań geograficzno-osadniczych oraz możliwości zastosowania ich w planowaniu przestrzennym, J. E. Żółtowska (2016). 
sposób zdefiniowanego regionu europejskiego jest kwestią dyskusyjną ${ }^{3}$. Zagadnienia rozległości przestrzennej i układu granicznego przyjętego do analizy obszaru, mogą budzić wątpliwości, należy jednak kierować się przydatnością wybranej procedury delimitacyjnej do realizowanego zamierzenia badawczego. W przypadku podjętego zadania określone terytorium spełnia wymogi adekwatności geograficznej.

Przyjęte do analizy statystycznej terytorium obejmuje 1903 tys. $\mathrm{km}^{2}$ i według danych z 2015 r. zamieszkuje je około 153810,5 tys. osób, z tego 100817 tys. stanowi ludność miejska. Stopień urbanizacji jest dość wysoki (64,7\%), chociaż zróżnicowany (najwyższy na Białorusi (77,3\%), zaś najniższy w Mołdawii (41,7\%) (tab. 1).

Tabela 1

\section{Liczba ludności w państwach polożonych na pomoście baltycko-czarno- morskim około 2015 r.}

\begin{tabular}{|c|c|c|c|c|c|}
\hline \multirow{3}{*}{ Lp. } & \multirow{3}{*}{ Państwo } & \multirow{3}{*}{$\begin{array}{c}\text { Powierzchnia } \\
\text { w tysiącach } \\
\text { km }^{2}\end{array}$} & \multicolumn{3}{|c|}{ Liczba ludności } \\
\hline & & & \multirow[b]{2}{*}{ w tysiącach } & \multicolumn{2}{|c|}{ w tym mieszkańcy miast } \\
\hline & & & & w tysiącach & $\begin{array}{c}\text { udzial } \\
\text { procentowy }\end{array}$ \\
\hline 1 & Białoruś & 207,6 & 9480,9 & 7325,0 & 77,3 \\
\hline 2 & Bułgaria & 111,0 & 7364,6 & 5338,3 & 72,5 \\
\hline 3 & Republika Czeska & 78,9 & 10512,4 & 7866,4 & 74,8 \\
\hline 4 & Estonia & 45,2 & 1280,9 & 864,6 & 67,5 \\
\hline 5 & Litwa & 65,2 & 2971,9 & 1989,3 & 66,9 \\
\hline 6 & Łotwa & 64,6 & 2001,5 & 1357,7 & 67,8 \\
\hline 7 & Mołdawia & 33,7 & 3559,5 & 1485,7 & 41,7 \\
\hline 8 & Polska & 312,7 & 38496,0 & 23258,0 & 60,4 \\
\hline 9 & Rumunia & 238,4 & 19942,0 & 11774,5 & 54,6 \\
\hline 10 & Słowacja & 49,0 & 5415,9 & 2929,0 & 54,1 \\
\hline 11 & Ukraina & 603,7 & 42929,3 & 29673,1 & 69,1 \\
\hline 12 & Węgry & 93,0 & 9855,6 & 6956,0 & 70,3 \\
\hline \multicolumn{2}{|c|}{ Ogółem } & 1903,0 & 153810,5 & 100817,0 & 64,7 \\
\hline
\end{tabular}

Źródło: Roczniki statystyczne i inne materiały źródłowe dotyczące poszczególnych państw:

- Białoruś: National statistical Committee of the Republic of Belarus, Minsk city 2015, s. 54; GeoHive Urban (rural division of countries for the years 2015 and 2025) - Biatoruś, 15.01.2016;

- Bulgaria: Republic of Bulgaria, National Statistical Institute 2014, Sofia 2015, s. 62; GeoHive Urban (rural division of countries for the years 2015 and 2025) - Butgaria, 15.01.2016.

3 Federacja Rosyjska graniczy również z Bałtykiem i Morzem Czarnym, pomimo tego włączenie jej w całości lub części zachodniej do tzw. pomostu bałtycko-czarnomorskiego nie wydaje się uzasadnione. 
- Czechy: Statistical Yearbook of the Czech Republic 2014, Czech Statistical Office, Praha 2014, s. 73; GeoHive Urban (rural division of countries for the years 2015 and 2025) - Republika Czeska, 15.01.2016.

- Estonia: List of cities in the Baltic states by population, 2010-2015, Estonia, 27.11.2017; GeoHive Urban (rural division of countries for the years 2015 and 2025) - Estonia, 15.01.2016.

- Litwa: Statistical Yearbook of Lithuania 2013, Statistics Lithuania, Vilnius 2013; List of cities in the Baltic states by population, 2012, 2013, 2015, Litwa, 27.11.2017.

- Lotwa: Statistical Yearbook of Latvia 2014, Central Statistical Buremu of Latvia, Riga 2015, s. 88-89, 92; List of cities in the Baltic states by population, 2011, 2014, 2015, Eotwa, 27.11.2017.

- Moldawia: Statistical Yearbook of the Republic of Moldova 2012, National Buremu of Statistics of the Republic of Moldova, Chişinău 2012, s. 32; GeoHive Urban (rural division of countries for the years 2015 and 2025) - Motdawia, 15.01.2016.

- Polska: Rocznik Statystyczny Rzeczypospolitej Polskiej, Główny Urząd Statystyczny, Warszawa 2015, s. 206, 214-216.

- Rumunia: National Institute of Statistics Romanian Statistical Yearbook 1990-2012, Bucharest 2014; National Institute of Statistics Romania in Figures, Bucharest 2014; GeoHive Urban (rural division of countries for the years 2015 and 2025) - Rumunia, 15.01.2016.

- Slowacja: Regional Statistical Yearbook of Slovakia 2014, Statistical Office of the Slovak Republic, Bratislava 2014, s. 17, 402-404.

- Ukraina: Statistical Yearbook of Ukraine for 2014, State Statistics Sernice of Ukraine, Pablishing House „Konsultant” Ltd., Kyiv 2015, s. 321, 326-327.

- Węgry: Statistical Yearbook of Hungary 2014, Hungarian Central Statistical Office, Budapest 2015; Hungary - Population, 2015, 27.11.2017; List of cities and towns in Hungary, Population 2013, Szombathely 2012, 15.01.2016.

Przystępując do oceny sytuacji demograficznej w poszczególnych państwach, należy zwrócić uwagę na istniejące dysproporcje w ich wielkościach powierzchniowych oraz potencjale ludnościowym. Rozpiętości między poszczególnymi analizowanymi jednostkami politycznymi są bardzo duże. Na Ukrainie żyje ponad 33,5 razy więcej ludności niż w Estonii. W trzech krajach bałtyckich (w Estonii, na Litwie i Łotwie) mieszka około sześć razy mniej osób niż w Polsce. Różnice w wielkościach terytorialnych rozpatrywanych państw są także wysokie. $Z$ tego względu wszelkie porównania wymagają dużej ostrożności interpretacyjnej.

$\mathrm{Na}$ przyjętym do analizy obszarze obejmującym 12 państw znajdują się miasta o różnej skali wielkości. Z tego względu podejmując studia nad osadnictwem miejskim zachodzi potrzeba przyjęcia pewnych założeń upraszczających i zawężających zakres opracowania. Podstawowy cel badawczy będzie jedynie ograniczony do przedstawienia roli miast stołecznych oraz rozpatrzenia różnic wielkościowych, jakie zachodzą w ramach dziesięciu największych ośrodków miejskich w każdym z krajów. 
Analiza istniejących w wybranych państwach centrów stołecznych wymaga wprowadzenia historycznego. Wynika to z faktu, że obok stolic, które mają za sobą długi okres pełnienia tej funkcji, mamy również do czynienia z ośrodkami, które uzyskały status stołeczny stosunkowo niedawno. W ciągu całego XX w., szczególnie w tej części Europy miały miejsce wielkie przesunięcia graniczne, które wiązały się z kreowaniem, względnie z likwidacją jednostek politycznych. Do I wojny światowej na badanym obszarze istniały tylko trzy ośrodki stołeczne: Bukareszt, Sofia oraz Budapeszt będący stolicą Królestwa Węgierskiego i częścią składową Cesarstwa Austro-Węgierskiego. Nowych pięć stolic niepodległych państw: Praga, Warszawa, Kowno ${ }^{4}$, Ryga i Tallin ukonstytuowało się po 1918 r. i w okresie międzywojennym funkcjonowało 8 miast stołecznych. Po utracie suwerenności przez trzy państwa bałtyckie (Estonię, Litwę i Łotwę) uległa zmniejszeniu liczba stolic (pominięto w rozważaniach republiki byłego Związku Sowieckiego). Dlatego też po zakończeniu II wojny światowej, w latach 1945-1991 na wyodrębnionym terytorium było jedynie pięć ośrodków stołecznych (Warszawa, Praga, Budapeszt, Bukareszt i Sofia). Dopiero rozpad Związku Sowieckiego oraz podział Czechosłowacji zmieniły diametralnie układ geopolityczny tej części Europy. Status stołeczny uzyskało siedem nowych miast, a mianowicie: Tallin, Ryga, Wilno, Mińsk, Kijów, Kiszyniów i Bratysława. Ustalony wówczas układ polityczny okazał się trwały $i$ istnieje do dnia dzisiejszego. Największym ośrodkiem spośród wymienionych jest Kijów liczący więcej niż 2,8 mln mieszkańców. W grupie między 1,7 mln a 1,9 mln ludności znajdują się: Mińsk, Bukareszt, Budapeszt i Warszawa, a następnie na poziomie około 1,2 mln utrzymują się: Praga i Sofia. Pozostałe miasta są już mniejsze, w tym dwa, nie osiagają wielkości granicznej 0,5 mln - Tallin i Bratysława (tab. 2).

Dzisiejszy stan demograficzny wymienionych miast jest rezultatem ich długoletniego rozwoju. Uwarunkowania historyczne, polityczne i gospodarcze wpłynęły na nierównomierne tempo wzrostu ludności. W celu ukazania dynamiki rozwojowej przyjętych do analizy ośrodków stołecznych przedstawiono dane demograficzne dla pięciu przekrojów czasowych (1900, 1930, 1960, 2000 i około 2015). Zaprezentowany, ponad stuletni okres daje możliwość wnikliwej oceny stopnia szybkości zmian w poszczególnych ośrodkach w całym ubiegłym stuleciu i na początku bieżącego wieku (tab. 2).

${ }^{4}$ W okresie międzywojennym faktyczną stolicą Litwy było Kowno, gdyż Wilno należało do Polski. 
Liczba ludności w ośrodkach stołecznych na tzw. pomoście baltycko-czarnomorskim w XX i na początku XXI wieku

\begin{tabular}{|c|c|c|c|c|c|c|c|c|c|c|c|}
\hline \multirow{3}{*}{ Lp. } & \multirow{3}{*}{ Mias } & \multicolumn{10}{|c|}{ Liczba ludności oraz pozycja wielkościowa } \\
\hline & & \multicolumn{2}{|c|}{ około 1900 r. } & \multicolumn{2}{|c|}{ około $1930 \mathrm{r}$. } & \multicolumn{2}{|c|}{ okolo $1960 \mathrm{r}$. } & \multicolumn{2}{|c|}{ około $2000 \mathrm{r}$. } & \multicolumn{2}{|c|}{ około 2015 r. } \\
\hline & & $\begin{array}{c}\text { w ty- } \\
\text { siącach }\end{array}$ & $\begin{array}{c}\text { ran- } \\
\text { ga }\end{array}$ & $\begin{array}{c}\text { w ty- } \\
\text { siącach }\end{array}$ & $\begin{array}{c}\text { ran- } \\
\text { ga }\end{array}$ & $\begin{array}{c}\text { w ty- } \\
\text { siącach }\end{array}$ & $\begin{array}{c}\text { ran- } \\
\text { ga }\end{array}$ & $\begin{array}{c}\text { w ty- } \\
\text { siącach }\end{array}$ & 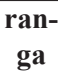 & $\begin{array}{c}\text { w ty- } \\
\text { siącach }\end{array}$ & $\begin{array}{r}\text { ran } \\
\text { ga }\end{array}$ \\
\hline 1 & ijów & 225 & VI & 539 & V & 1109 & IV & 2618,0 & I & 2888,0 & I \\
\hline 2 & Iińsk & 85 & IX & 15 & $\mathrm{X}$ & 509 & VIII & 1688,0 & IV & 1938,3 & II \\
\hline 3 & ukar & 281 & V & 639 & IV & 1226 & II & 2016,1 & II & 1883,4 & III \\
\hline 4 & udap & 716 & I & 1043 & II & 819 & I & 1811,5 & III & 1735,7 & IV \\
\hline 5 & Jarsz & 638 & II & 1131 & 1 & 36 & III & 3,5 & $\mathrm{~V}$ & 1735,4 & V \\
\hline 6 & aga & 475 & III & 677 & III & 0 & $\mathrm{~V}$ & & VI & 1243,2 & VI \\
\hline 7 & ofia & 82 & $\mathrm{X}$ & 15 & 12 & 2 & VI & 11 & VII & 1221,3 & VII \\
\hline 8 & iszyn & 08 & VIII & 168 & VIII & 216 & XII & 3,0 & IX & 723,5 & VII \\
\hline 9 & yga & 282 & IV & 338 & VI & 580 & VII & 3,2 & VIII & 641,0 & IX \\
\hline 10 & Vilno & 140 & VII & 195 & VII & 236 & XI & 577,9 & $\mathrm{X}$ & 542,7 & $\mathrm{X}$ \\
\hline 11 & Tallinn & 66 & $\mathrm{XI}$ & 122 & XII & 282 & IX & 442,7 & XII & 436,6 & $\mathrm{XI}$ \\
\hline 12 & 3ratysława & 65 & XII & 124 & XI & 258 & $\mathrm{X}$ & 449,5 & XI & 417,4 & $\mathrm{XI}$ \\
\hline
\end{tabular}

Źródło: Wcześniej wymienione (przy tabeli 1) roczniki statystyczne poszczególnych państw i inne pozycje statystyczne.

Na przełomie XIX i XX wieku największym z omawianych miast był Budapeszt, po nim plasowała się - Warszawa. Tylko te dwie stolice przekraczały wielkość $0,5 \mathrm{mln}$, a z pozostałych do tej granicy zbliżała się jedynie Praga. W połowie lat międzywojennych (około 1930 r.) Warszawa i Budapeszt były już na ówczesne czasy metropoliami, gdyż przekroczyły 1,0 mln mieszkańców. Zbliżony do siebie potencjał demograficzny reprezentowały Bukareszt i Praga. Graniczną wielkość 0,5 mln mieszkańców ponadto przekroczył Kijów. Pomimo strat wywołanych wojną, około 1960 r. na analizowanym obszarze były już cztery miasta stołeczne o liczbie ludności powyżej 1,0 mln, w tym najbardziej zniszczona w czasie wojny Warszawa. W ostatnim przekroju czasowym pokazującym sytuację współczesną wśród 12 stolic - siedem z nich przekroczyło poziom jednego miliona mieszkańców (Kijów, Mińsk, Bukareszt, Budapeszt, Warszawa, Praga i Sofia).

Nierównomierne tempo rozwoju demograficznego poszczególnych miast powodowało zmiany w uszeregowaniu wielkościowym. Przed ponad stu laty, największym miastem omawianego regionu był Budapeszt, następnie Warszawa. Kolejne miejsca zajmowały Praga, Ryga 
i Bukareszt. Na końcowych pozycjach znajdowały się: Mińsk, Sofia, Tallin i Bratysława. Po trzydziestu latach (w 1930 r.), pierwsze miejsce pod względem liczby ludności zajmowała Warszawa, a następnie Budapeszt, Praga i Bukareszt. Po II wojnie światowej uszeregowanie ponownie uległo zmianie. Na pierwszą pozycję powrócił Budapeszt a na drugie miejsce awansował Bukareszt. Zbliżony potencjał demograficzny miały Warszawa i Kijów. Kolejne, zachodzące zmiany ujawniły dane z około 2000 r. Największym miastem stał się Kijów - przed Bukaresztem i Budapesztem. Stolica Polski miała mniej ludności niż Mińsk, ale wyprzedziła znacznie Pragę i Sofię. W tym zakresie sytuacja między 2000 a 2015 rokiem nie uległa zmianie. Nadal funkcjonuje siedem ośrodków stołecznych o liczbie ludności powyżej 1 mln mieszkańców. W okresie ostatnich 15 lat Kiszyniów wyprzedził Rygę, zaś Tallin Bratysławę (tab. 2).

Obserwacja całego okresu stuletniego i początku XXI w., a zwłaszcza przesunięcia w uszeregowaniu stwarzają możliwości dokonania porównań. Wśród analizowanych miast, Warszawa w 1900 r. zajmowała pozycję druga, a obecnie (od 2000 r. i w 2015 r.) piątą. Analogicznie, obniżył swoją relatywną rangę Budapeszt z miejsca pierwszego na trzecie (2000 r.), a następnie na czwarte (2015 r.). Natomiast Kijów będący na szóstym miejscu w 1900 r., współcześnie (w 2000 r. i 2015 r.) zajmuje lokatę pierwszą. Podobnie, Mińsk awansował z pozycji dziewiątej na czwartą (2000 r.) i drugą (2015 r.) (tab. 2).

Przedstawiona analiza o charakterze porównawczym jest skonstruowana jedynie na wybranych danych demograficznych. Uwzględniając jeszcze inne parametry (np. siłę ekonomiczną lub finansową, różnorodność funkcji czy standard życia mieszkańców) uszeregowanie na pewno uległoby zmianie. Można na przykład sądzić, że pozycja Warszawy przy zbadaniu innych czynników stołeczności byłaby przypuszczalnie wyższa niż Mińska. Przy zawężeniu jednak procedury jedynie do liczby mieszkańców analiza danych statystycznych przyniosła rezultaty w pewnym stopniu nieoczekiwane. Między innymi okazało się, że najwyższym tempem rozwoju ludnościowego odznaczały się byłe miasta ZSRR niemające do przełomu lat 80. i 90. XX wieku pełnego statusu stołecznego (np. Kijów, Mińsk). Z kolei miasta o utrwalonej w Europie pozycji, jak Budapeszt, Praga czy Warszawa odznaczały się relatywnie wolną dynamiką demograficzną.

Rozpatrywane ośrodki stołeczne pełnią najważniejsze funkcje dyspozycyjne. Mieszczą się w nich władze państwa, parlamenty, instytucje 
centralne. Z uwagi na to, istotne jest ich położenie geograficzne. Jedynie trzy stolice (na 12) mają dogodne usytuowanie w samym centrum kraju (Praga, Mińsk oraz Kiszyniów). Kolejne trzy ośrodki stołeczne - Ryga, Tallin i Bratysława - położone są peryferyjnie, przy samej granicy państwa: i w tym, w pobliżu granicy lądowej - Bratysława, zaś nad morzem Ryga i Tallin. Pozostałe sześć stolic ma lokalizację pośrednią (nie można zakwalifikować jej ani do centralnej, ani do peryferyjnej). Znajdują się w pewnym oddaleniu zarówno od centrum kraju, jak i od granic politycznych.

Zazwyczaj miasta stołeczne powstawały na przecięciu ważnych połączeń komunikacyjnych. Tak też jest w przypadku wszystkich rozpatrywanych stolic. Badacze zajmujący się osadnictwem zwracają szczególną uwagę na rolę rzek i zbiorników wodnych przy ustalaniu genezy i rozwoju osiedli. Lokalizacja taka jest oczywiście widoczna w przypadku państw środkowo-wschodniej Europy i może świadczyć o starej metryce tych ośrodków. Wymienione miasta stołeczne ulokowane są nad rzekami, w tym niektóre w pobliżu wielkich europejskich cieków: Bratysława i Budapeszt leżą bezpośrednio nad Dunajem, Kijów nad Dnieprem, Warszawa nad Wisłą, Praga nad Wełtawą, Wilno przy ujściu Wilii do Niemna, Ryga zaś przy ujściu Dźwiny do Bałtyku. Położenie nad morzem i pełnione funkcje portowe zadecydowały o rozwoju Tallina i Rygi.

Pomimo, że stolice odgrywają zazwyczaj istotną rolę $\mathrm{w}$ systemie osadniczym własnego kraju to są, tylko jedynie, jednym z komponentów całościowego układu osadniczego, który składa się z większej lub mniejszej liczby jednostek osadniczych. Istnieją liczne zależności funkcjonalno-przestrzenne między stolicą a pozostałymi miastami i kwestie te są niezależnie omawiane w literaturze przedmiotu. Przeprowadza się liczne klasyfikacje, w których ocenia się w jakim stopniu stolica lub inne duże miasto dominuje nad pozostałymi ośrodkami miejskimi. Analizując uszeregowanie poszczególnych jednostek osadniczych wydziela się systemy tzw. monocentryczne lub policentryczne, które świadczą w sposób pośredni o randze poszczególnych miast w systemie osadniczym danego kraju.

Analizą statystyczną objęto dziesięć największych miast zestawionych według liczby mieszkańców. Ośrodek stołeczny (największy), zgodnie z założeniem otrzymał rangę nr 1, a liczba jego mieszkańców przyjęła wartość $100 \%$. Kolejne miasta ułożono stosownie z malejącym udziałem procentowym. Uzyskane rezultaty zostały przedstawione w tabeli statystycznej oraz na wykresie (tab. 3 i wykres 1). 
Tabela 3

Układ największych miast $w$ badanych państwach według reguły kolejności i wielkości G. K. Zipfa około 2015 r.

\begin{tabular}{|c|c|c|c|c|c|c|c|c|c|c|c|c|c|}
\hline \multirow[b]{2}{*}{$\dot{2}$} & \multirow[b]{2}{*}{ 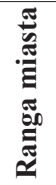 } & \multicolumn{12}{|c|}{ Udzial procentowy do miasta największego } \\
\hline & & 瓷 & 尝 & 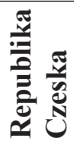 & 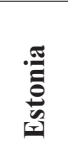 & 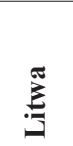 & لَّ & $\frac{\sqrt[\pi]{3}}{\frac{\pi}{0}}$ & $\begin{array}{l}\frac{\pi}{2} \\
\frac{\pi}{0} \\
\frac{0}{0}\end{array}$ & & $\begin{array}{l}\frac{\pi}{0} \\
\frac{\pi}{0} \\
\frac{0}{\sqrt{2}}\end{array}$ & & $\begin{array}{l}\overrightarrow{8} \\
3 \\
3\end{array}$ \\
\hline 1 & I & 100,0 & 100,0 & 100,0 & 100,0 & 100,0 & 100,0 & 100,0 & 100,0 & 100,0 & 100,0 & 100,0 & 100,0 \\
\hline 2 & II & 26,7 & 27,9 & 30,4 & 22,2 & 55,5 & 15,1 & 20,6 & 43,9 & 17,1 & 57,4 & 50,3 & 11,8 \\
\hline 3 & III & 19,3 & 27,4 & 23,8 & 14,2 & 29,0 & 11,2 & 19,9 & 40,7 & 16,4 & 21,8 & 35,2 & 9,4 \\
\hline 4 & IV & 18,9 & 16,3 & 13,5 & 9,5 & 19,9 & 8,9 & 12,9 & 36,6 & 16,1 & 19,5 & 34,3 & 9,3 \\
\hline 5 & $\mathrm{~V}$ & 18,6 & 12,1 & 8,2 & 8,5 & 17,5 & 7,7 & 6,9 & 31,4 & 15,8 & 19,0 & 32,4 & 8,5 \\
\hline 6 & VI & 17,3 & 11,3 & 8,0 & 4,6 & 10,5 & 5,7 & 5,7 & 26,6 & 15,7 & 18,8 & 26,4 & 7,4 \\
\hline 7 & VII & 11,3 & 8,4 & 7,5 & 3,8 & 7,3 & 4,7 & 5,3 & 23,5 & 15,2 & 15,8 & 25,2 & 6,8 \\
\hline 8 & VIII & 9,2 & 7,3 & 7,5 & 3,8 & 6,7 & 3,8 & 5,2 & 20,6 & 14,6 & 13,5 & 22,4 & 6,4 \\
\hline 9 & IX & 7,5 & 7,3 & 7,5 & 3,7 & 5,5 & 3,7 & 4,6 & 19,7 & 11,9 & 13,4 & 17,1 & 5,7 \\
\hline 10 & $\mathrm{X}$ & 7,1 & 6,5 & 7,2 & 3,4 & 5,1 & 3,6 & 3,5 & 17,4 & 10,9 & 12,6 & 15,7 & 4,6 \\
\hline
\end{tabular}

Źródło: Wcześniej wymienione (przy tabeli 1) roczniki statystyczne poszczególnych państw i inne pozycje statystyczne.

Wykres 1. Układ największych miast według reguły kolejności i wielkości G. K. Zipfa około 2015 r.

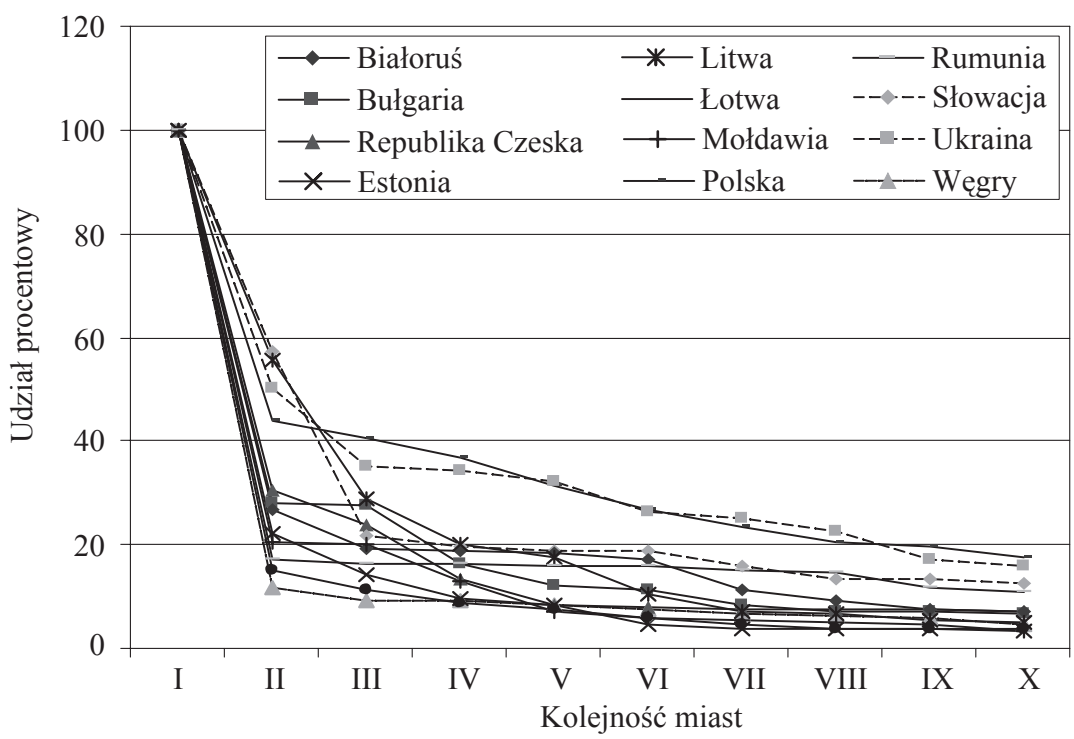

Źródło: Wcześniej wymienione (przy tabeli 1) roczniki statystyczne poszczególnych państw i inne pozycje statystyczne. 
Według regularnego układu zaproponowanego przez G. K. Zipfa, miasto rangi $\mathrm{nr} 2$ powinno mieć stosownie z założeniem 50,0\% udziału w relacji do ośrodka największego. Kolejne, rangi nr $3-33,3 \%$, nr 4 $-25,0 \%$, nr $5-20,0 \%$, nr $6-16,6 \%$, nr $7-14,3 \%$, nr $8-12,6 \%$, nr 9 - $11,1 \%$ i rangi $\mathrm{nr} 10$ - równe $10,0 \% \mathrm{w}$ stosunku do miasta rangi nr 1 .

Określone udziały procentowe zestawione dla 12 rozpatrywanych państw ujawniły, że istnieje niewielka zgodność między układem teoretycznym, przedstawionym przez G. K. Zipfa, a stanem rzeczywistym. Zwłaszcza rozbieżności dotyczą miast największych. Porównując układy poszczególnych jednostek miejskich między sobą, można przeprowadzić klasyfikację, a nawet typologię rozkładów wielkościowych. Istnieje również możliwość wydzielenia krajów odznaczających się monocentryzmem lub policentryzmem. Do pierwszej grupy należą państwa, w których stolica, czyli miasto rangi $\mathrm{nr}$ 1, dominuje nad pozostałymi, zwłaszcza zaś nad miastami rangi nr 2. Znamiennym przykładem mogą być Węgry, w państwie tym Budapeszt (pozycja nr 1) jest ponad ośmiokrotnie większy od miasta rangi nr 2 (Debreczyna). Podobnym układem monocentrycznym, czyli dominacją stolicy, cechuje się system osadniczy Łotwy i Rumunii. Diametralnie innymi relacjami między stolicą a pozostałymi miastami, charakteryzują się układy osadnicze Polski i Ukrainy. Pod tym względem są one do siebie zbliżone i należą do typowych układów policentrycznych. Między kolejnymi miastami, w obu tych państwach, występują stosunkowo niewielkie dysproporcje wielkościowe. Interesujące rezultaty daje porównanie miast rangi $\mathrm{nr} 5$ i rangi nr 10 - do ośrodka największego. W przypadku układu osadniczego Węgier, Łotwy, Mołdawii czy Estonii, mamy do czynienia z wielkimi dysproporcjami wielkościowymi. Miasta na tych pozycjach w układach osadniczych Polski i Ukrainy mają stosunkowo wysoką wartość wskaźników procentowych. Zaistniałe różnice wskazują na skalę mono- lub policentryzmu. Czynnikami wywołującymi takie czy inne rozkłady wielkościowe mogą być m.in. różnorodne przyczyny: polityczne, historyczne, geograficzne. Ponadto należy zwrócić uwagę, że rozkłady wielkościowe miast mają istotne konsekwencje dla przestrzennego rozmieszczenia ludności oraz usytuowania najważniejszych elementów zagospodarowania kraju.

Przedstawione rozważania na temat skali mono- i policentryzmu układów osadniczych oraz rangi ośrodka stołecznego w analizowanych państwach stanowią punkt wyjścia do dalszej analizy statystycznej. Uwzględniają one bowiem, jedynie relacje pomiędzy wielkością zalud- 
nienia kolejnych dziewięciu miast do miasta największego. Pomijają natomiast bardzo istotną kwestię związaną ze stopniem koncentracji ludności w tych miastach w stosunku do ogólnego zaludnienia kraju, jak i do ludności miejskiej.

Poniższą część analizy skonstruowano na podstawie tzw. krzywej Lorentza, metody badania stopnia koncentracji zjawisk występujących w przestrzeni społeczno-gospodarczej. Zasada oceny stopnia koncentracji polega na obliczeniu procentu zaludnienia poszczególnych miast od największego do najmniejszego w stosunku do całkowitej liczby ludności. W celu przedstawienia wspomnianego rozkładu na wykresie wykorzystujemy udziały skumulowane, czyli dodajemy do siebie kolejne wskaźniki procentowe. Liczba ludności danego kraju przy tym założeniu została przyjęta jako $100 \%$. Konfiguracja krzywych na wykresie graficznym pokazuje stopień koncentracji, czyli rozkład skupienia ludności w największych ośrodkach miejskich w badanych jednostkach politycznych (tab. 4 i wykres 2).

Tabela 4

Stopień koncentracji ludności w największych miastach w stosunku do zaludnienia kraju w około 2015 r.

\begin{tabular}{|c|c|c|c|c|c|c|c|c|c|c|c|c|c|}
\hline \multirow[b]{2}{*}{$\dot{\dot{\alpha}}$} & \multirow{2}{*}{ 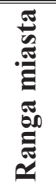 } & \multicolumn{12}{|c|}{ Skumulowany udział procentowy w stosunku do ludności kraju } \\
\hline & & $\frac{\text { 先 }}{\frac{0}{3}}$ & 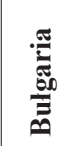 & 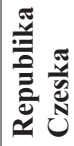 & 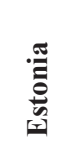 & $\sum_{=}^{\frac{\pi}{3}}$ & لِ & $\frac{\pi}{\frac{\pi}{2}}$ & $\frac{\pi}{\frac{\pi}{0}}$ & & $\begin{array}{l}\frac{\pi}{\tilde{\pi}} \\
\frac{0}{0} \\
\frac{0}{\sigma}\end{array}$ & 丞 & $\overbrace{0}^{\infty}$ \\
\hline 1 & I & 20,4 & 16,6 & 11,8 & 34,1 & 18 , & 3 & 20, & & 9,4 & 7, & 67 & 17 , \\
\hline 2 & II & 25,9 & 2 & ד, & T1, & 28 & 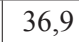 & 24,5 & & 110 & 12 & 10 & 19 , \\
\hline 3 & III & 29,8 & 25,8 & 18,2 & 46,5 & 33 & 40 & 28 , & & 12 & 13 & 12 & 21 , \\
\hline 4 & IV & 33,7 & 28,5 & 19,8 & $4 c$ & 37,3 & 43,3 & 3 & 10,0 & 141 & 153 & 14 & 23 \\
\hline 5 & V & 37,5 & 30,5 & 20,8 & 52,6 & 40 & 45 & 32,6 & 4 & j & 10 & 17,0 & 24, \\
\hline 6 & VI & 41,1 & 32,3 & 21,7 & 54,2 & 4 & 47 & 33,7 & 12 & 17,1 & 18 & 18,7 & 25 , \\
\hline 7 & VII & 43,4 & 33,7 & 22,6 & 55,5 & 4 & 4 & 3 & 1. & 10,3 & 17,4 & 20,4 & 27, \\
\hline 8 & VIII & 45,2 & 35,0 & 23,5 & 56,8 & 45,0 & 50,3 & 35,9 & 14,6 & 19,9 & 20 & 21,9 & 28 , \\
\hline 9 & IX & 46,8 & 36,2 & 24,4 & 58,1 & 46 & 51,5 & 36,8 & 15,5 & 21,0 & 21,5 & 23,1 & 29 , \\
\hline 10 & $\mathrm{X}$ & 48,2 & 37,3 & 25,2 & 59,2 & 46,9 & 52,7 & 37,5 & 16,2 & 22,1 & 22,5 & 24,2 & 29 , \\
\hline \multicolumn{2}{|c|}{$\begin{array}{l}\text { Ludność } \\
\text { kraju }\end{array}$} &, 0 & 0,0 & 100,0 & 100,0 & 100,0 & 100,0 & 100,0 & 100,0 & 00,0 & 00,0 & 100,0 & 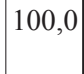 \\
\hline
\end{tabular}

Źródlo: Wcześniej wymienione (przy tabeli 1) roczniki statystyczne poszczególnych państw i inne pozycje statystyczne. 
Wykres 2. Stopień koncentracji ludności w największych miastach w stosunku do zaludnienia kraju w ok. 2015 r.

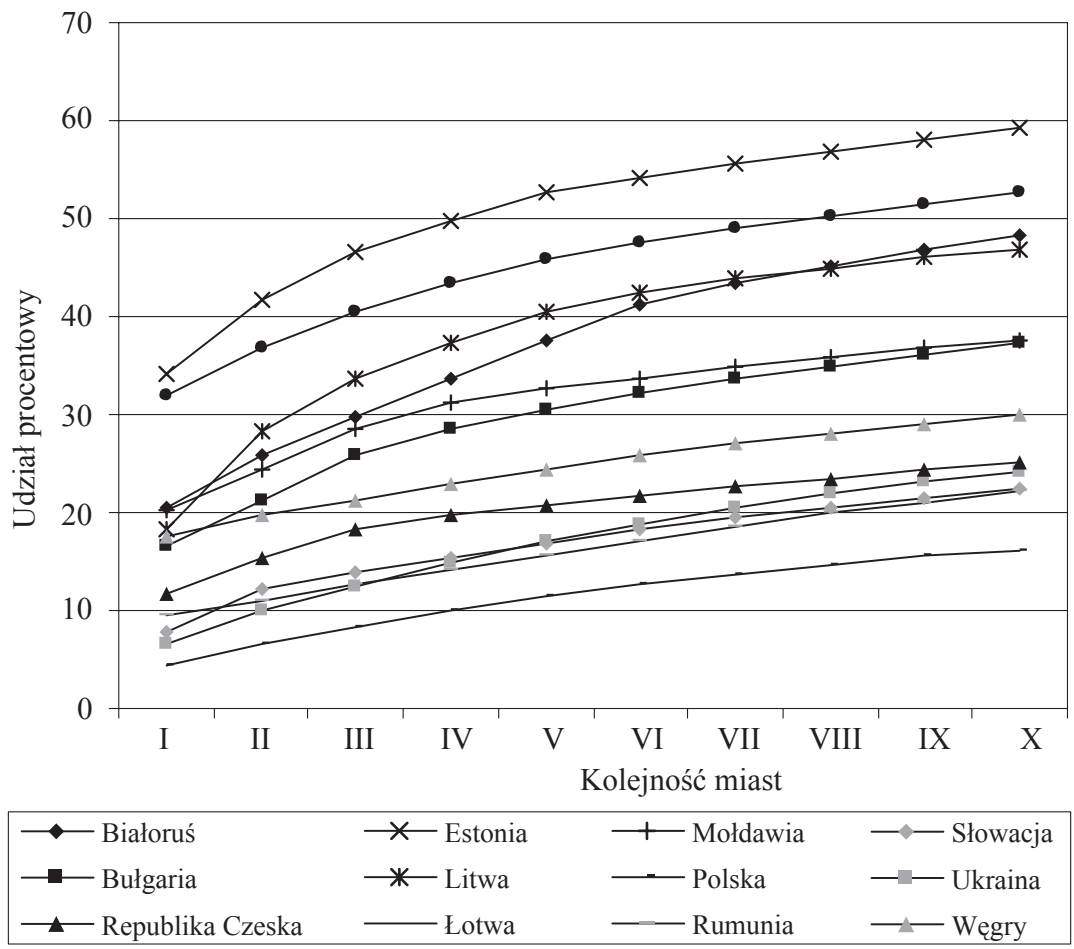

Źródło: Wcześniej wymienione (przy tabeli 1) roczniki statystyczne poszczególnych państw i inne pozycje statystyczne.

Analiza rozkładów procentowych wykazuje wielkie różnice między stopniem koncentracji ludności w największych ośrodkach miejskich. W krajach takich, jak na przykład Łotwa, blisko 1/3 obywateli państwa skupia się w stolicy, a w dziesięciu największych miastach koncentruje się ponad połowa zaludnienia kraju. Podobnie powyżej 50\% ludności Estonii zamieszkuje w dziesięciu największych miastach. Ponad 40\% ludności kraju znajduje się w dziesięciu największych ośrodkach na Litwie i Białorusi. Odmienna sytuacja ma miejsce w Polsce, która ze wszystkich omawianych krajów cechuje się najniższym stopniem koncentracji przestrzennej ludności. Odgrywa tu pewną rolę wielkość kraju, ale głównie jest to związane z silnie ukształtowanym policentryzmem układu osadniczego. Każde z rozpatrywanych państw odznacza się swoją wyraźnie wyodręb- 
nioną specyfiką. Zbliżony do siebie stopień skupienia ludności występuje na Słowacji i w Republice Czeskiej. Identyczne relacje w skali koncentracji przestrzennej ludności mają miejsce w Rumunii i na Ukrainie.

Analogiczną analizę statystyczną można również przeprowadzić przyjmując jako wielkości odniesienia nie potencjał demograficzny całego kraju, lecz liczbę ludności miejskiej (zasady metodyczne są identyczne). Wyliczone wskaźniki procentowe, a następnie ich zestawienie w szeregu skumulowanym daje możliwość przedstawienia stopnia koncentracji zaludnienia w relacji do ludności miejskiej (tab. 5 i wykres 3).

Tabela 5

Stopień koncentracji ludności w największych miastach w stosunku do zaludnienia miast w około 2015 r.

\begin{tabular}{|c|c|c|c|c|c|c|c|c|c|c|c|c|c|}
\hline \multirow[b]{2}{*}{$\dot{2}$} & \multirow{2}{*}{ 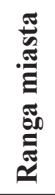 } & \multicolumn{12}{|c|}{ kumulowany udział procentowy w stosunku do ludności miejskiej } \\
\hline & & 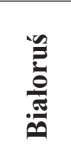 & 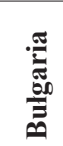 & 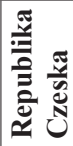 & 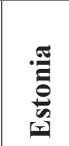 & $\sum_{S}^{\pi}$ & لَّ & $\frac{\pi}{\frac{\pi}{3}}$ & $\frac{\pi}{\frac{\pi}{0}}$ & 㩊 & $\begin{array}{l}\frac{\pi}{0} \\
\frac{\pi}{2} \\
\frac{\pi}{6}\end{array}$ & & $\vec{b}^{\infty}$ \\
\hline 1 & I & כ, & & 8 & & & & & & & & & 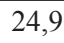 \\
\hline 2 & Il & 35 & & 5 & & & 42 & & & & & & 270 \\
\hline 3 & III & & & 244 & & & & & & & & & \\
\hline 4 & IV & o & & 26,5 & & & & & & & & & 2 , \\
\hline 5 & $\mathrm{y}$ & 6 & & 2 & & & 67,5 & & 18,8 & & & 24 & 4. \\
\hline 6 & VI & 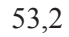 & & 25,1 & & & & & & & & & , \\
\hline 7 & & 56,1 & & 30,2 & & & & & & & & & 38, \\
\hline 8 & VIII & 86 & 48,2 & 31,4 & 84,1 & & 74,2 & 86,0 & 24,1 & 33,7 & 37,9 & 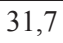 & 39 \\
\hline 9 & IX & 60,5 & 49,9 & 32,6 & & & & & & & & & 41,3 \\
\hline 10 & $\mathrm{X}$ & 2,4 & & 33,7 & & 70,1 & 77,7 & 90,0 & 26,9 & 37 & 41,6 & 34,9 & 42,4 \\
\hline
\end{tabular}

Źródło: Wcześniej wymienione (przy tabeli 1) roczniki statystyczne poszczególnych państw i inne pozycje statystyczne.

Przyjęcie jako podstawy odniesienia nie całej ludności kraju, lecz jedynie zaludnienia w miastach przyniosło odmienne rezultaty. Wyliczone wskaźniki procentowe odnoszą się do mniejszej populacji, więc też przybrały wyższe wartości. Podobnie jak w poprzednich zestawieniach tabelarycznych najniższym stopniem koncentracji przestrzennej odznacza się układ osadniczy Polski. W dziesięciu największych ośrodkach miejskich naszego kraju skupia się 26,9\% ludności miejskiej. Diametralnie inna sytuacja ma miejsce w krajach bałtyckich (Estonia - 87,7\%; Łotwa 
- 77,7\%) czy w Mołdawii, gdzie rozpatrywany stopień koncentracji jest niezmiernie wysoki i wynosi 90,0\%. Ponad połowa ludności miejskiej skupia się w dziesięciu największych miastach na Litwie (70,1\%), Białorusi $(62,4 \%)$ i w Bułgarii (51,4\%).

\section{Wykres 3. Stopień koncentracji ludności w największych miastach w stosunku do zaludnienia miast w ok. 2015 r.}

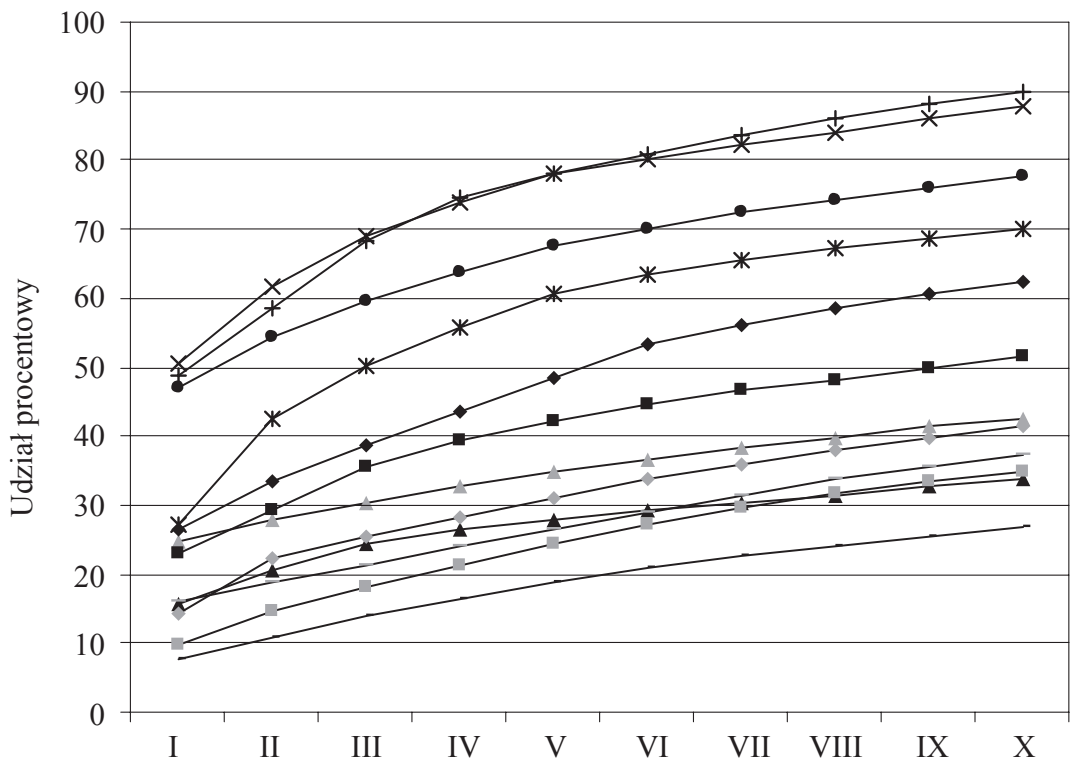

Kolejność miast

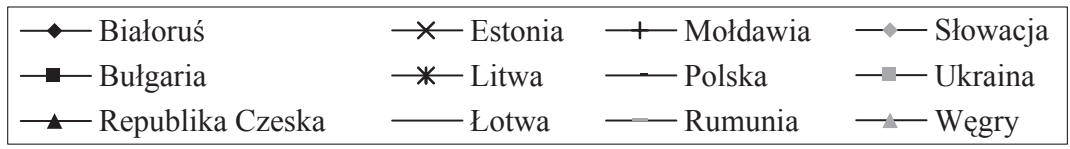

Źródło: Wcześniej wymienione (przy tabeli 1) roczniki statystyczne poszczególnych państw i inne pozycje statystyczne.

Przeprowadzona analiza geograficzna i zestawione procentowe wyliczenia statystyczne oraz załączone wykresy pokazują różnice i podobieństwa, jakie zachodzą w osadnictwie wielkomiejskim w omawianych jednostkach politycznych. Głównym celem podjętego zadania badawczego było ukazanie drogi metodycznej, która miała ujawnić stopień koncentracji, a także rozkład wielkościowy jednostek osadniczych. Ostateczne wy- 
niki ujawniły przydatność zastosowanej metody, którą można dowolnie rozszerzać na większą liczbę państw i miast.

Niniejsze badania statystyczne zostały zawężone do konkretnego, dość arbitralnie wyodrębnionego obszaru, który jest częścią większego terytorium, gdzie znajdują się miasta o różnej wielkości i usytuowaniu geograficznym. Miasta te o randze metropolitalnej oddziałują na cały obszar objęty analizą, a należą do nich Berlin, Wiedeń, Moskwa i Stambuł (zagadnienia te jednak wykraczają poza zakres podjętego tematu).

Rozważania skoncentrowano na rozpatrzeniu sytuacji w wybranych 12 państwach (przyjęcie innego obszaru dałoby przypuszczalnie inne rezultaty). Przetestowana metoda z wykorzystaniem teorii G. K. Zipfa i tzw. krzywej M. O. Lorentza okazała się użyteczna i rozszerzająca wiedzę geograficzną o rozkładzie i wielkości miast.

Podsumowując, powinno się podać kilka aktualnych informacji o największych miastach położonych na analizowanym obszarze. Większość dużych miast usytuowanych na pomoście bałtycko-czarnomorskim to ośrodki stołeczne, w tym jedno - Kijów o zaludnieniu powyżej 2,8 mln, Mińsk (1,9 mln), Bukareszt $(1,8)$, dwa: Budapeszt i Warszawa po $1,7 \mathrm{mln}$ czy też Praga i Sofia po 1,2 mln mieszkańców oraz między 0,5-0,7 mln (Kiszyniów, Ryga, Wilno) i poniżej 500 tys. osób: Tallin i Bratysława. Z innych miast na terenie Ukrainy powyżej miliona ludności posiadają: Charków $(1,4 \mathrm{mln})$ i Odessa $(1,0 \mathrm{mln})$, ponadto do analizowanej wielkości zbliżają się: Dniepropietrowsk i Donieck. Ośrodków miejskich o zaludnieniu od 0,5 $\mathrm{mln}$ do 1,0 mln, łącznie jest 8, w tym: trzy na Ukrainie (Zaporoże, Lwów, Krzywy Róg), cztery w Polsce (Kraków, Łódź, Wrocław, Poznań) i na Białorusi - Homel. W rozpatrywanym okresie wymienione miasta zmieniały swoją range i miejsce w rozkładzie ułożonym według wielkości. Jako przykład możemy zaproponować uszeregowanie największych miast w Polsce. Do przełomu XX i XXI wieku drugim pod względem potencjału demograficznego ośrodkiem była Łódź a obecnie jest nim Kraków. Przypuszczalnie w ciagu kilkunastu najbliższych lat zmieni się ponownie ranga Łodzi na korzyść Wrocławia i Poznania.

Wszystkie miasta, stołeczne, jak i pozostałe, pomimo czasami dużych różnic, jakie między nimi zachodza, odgrywają istotną rolę jako skupiska ludności. Równocześnie stanowią one centra polaryzacji działalności gospodarczo-społecznej, a przede wszystkim pełnią funkcje centralne wobec otaczających obszarów. 


\section{ZAŁĄCZNIK \\ Zestawienie przyjętych do analizy największych miast (dane w tys. mieszkańców)}

Białoruś: 1) Mińsk (Mensk) - 1938,3; 2) Homel (Gomel) - 517,0; 3) Mohylew (Mogilov) - 374,7; 4) Witebsk (Vitebsk) - 366,3; 5) Grodno - 361,5; 6) Brześć (Brest) - 335,6; 7) Bobrujsk - 218,3; 8) Baranowicze (Baranoviči) - 179,0; 9) Borysów (Borisov) - 144,9, 10) Pińsk (Pinsk) $-\mathbf{1 3 7 , 5}$.

Bulgaria: 1) Sofia (Sofija) - 1221,3; 2) Plowdiw (Plovdiv) - 341,0; 3) Warna (Varna) - 335,8; 4) Burgas - 199,4; 5) Ruse - 147,8; 6) Stara Zagora - 137,8; 7) Plewen (Pleven) - 103,1; 8) Sliwen (Sliven) - 89,7; 9) Dobricz (Dobrič) - 88,8; 10) Szumen (Šumen) - 79,7.

Czechy: 1) Praga (Praha) - 1243,2; 2) Brno - 377,5; 3) Ostrawa (Ostrava) - 295,7; 4) Pilzno (Plzeň) - 168,0; 5) Liberec - 102,3; 6) Olomuniec (Olomouc) - 99,5; 7) Usti nad Labą (Ustí nad Laben) - 93,5; 8) Czeskie Budziejowice (Česke Budějovice) - 93,3; 9) Hradec Kralowe (Hradec Králové) - 92,9; 10) Pardubice - 89,4.

Estonia: 1) Tallin (Tallinn) - 436,6; 2) Tartu (Tartu) - 97; 3) Narwa (Narva) - 62,1; 4) Parnawa (Pärnu) - 41,5; 5) Kohtla-Järve - 37,2; 6) Viljandi - 20,0; 7) Rakvere - 16,6; 8) Maardu - 16,5; 9) Sillämae - 16,2; 10) Kuressaare - 15,0.

Litwa: 1) Wilno (Vilnius) - 542,7; 2) Kowno (Kaunas) - 301,4; 3) Kłajpeda (Klajpeda) - 157,3; 4) Szawle (Šiauliai) - 107,9; 5) Poniewież (Panevėžys) - 95,2; 6) Olita (Alytus) - 57,3; 7) Mariampol (Marijampole) - 39,5; 8) Możejki (Mažeikiai) - 36,3; 9) Janów (Janova) - 29,7; 10) Vciana (Vtena) - 28,0.

Lotwa: 1) Ryga (Riga) - 641,0; 2) Dyneburg (Daugavpils) - 96,8; 3) Lipawa (Liepāja) - 71,9; 4) Mitawa (Jelgava) - 57,3; 5) Jarmuła (Jūrmala) - 49,7; 6) Windawa (Ventspils) - 36,7; 7) Rzeżyca (Rēzekne) - 29,9; 8) Orge-24,4; 9) Wolmar (Valmiera) - 23,7; 10) Jakubowo (Jēkabpils) $-23,3$.

Mołdawia: 1) Kiszyniów (Chişinău) - 723,5; 2) Tyraspol (Tiraspol) - 148,9; 3) Bielce (Bălti) - 144,3; 4) Bendery (Bender) - 93,7; 5) Rybnica (Rãbnita) - 50,1; 6) Kaguł (Cahul) - 41,1; 7) Ungheni - 38,5; 
8) Soroki (Soroca) - 37,5; 9) Orgiejów (Orhei) - 33,5; 10) Dubossary (Dubăsar) - 25,7.

Polska: 1) Warszawa - 1735,4; 2) Kraków - 761,9; 3) Lódź - 706,0; 4) Wrocław - 634,5; 5) Poznań - 545,7; 6) Gdańsk - 461,5; 7) Szczecin $-407,2$; 8) Bydgoszcz - 357,7; 9) Lublin - 341,7; 10) Katowice $-301,8$.

Rumunia: 1) Bukareszt (Bucureşti) - 1883,4; 2) Jassy (Jaşi) - 322,0; 3) Kluż (Cluj-Napoca) - 309,9; 4) Timisoara (Timişoara) - 303,0; 5) Konstanca (Constanța) - 298,0; 6) Craiova - 295,0; 7) Galacz (Galati) - 286,0; 8) Braszów (Braşov) - 275,0; 9) Plojeszti (Ploieşti) - 224,0; 10) Braila (Brăila) - 205,0.

Słowacja: 1) Bratysława (Bratislava) - 417,4; 2) Koszyce (Košice) - 239,8; 3) Preszów (Prešov) - 90,9; 4) Żilina (Žilina) - 81,3; 5) Bańska Bystrzyca (Banska Bystrica) - 79,4; 6) Nitra - 78,4; 7) Tarnawa (Trnava) $-66,0$; 8) Martin - 56,5; 9) Trenczin (Trenčin) - 55,9; 10) Poprad $-52,7$.

Ukraina: 1) Kijów (Kyiv) - 2888,0; 2) Charków (Kharkiv) - 1453,0; 3) Odessa (Odesa) - 1017,0; 4) Dniepropietrowsk (Dnipropetrovsk) - 990,0; 5) Donieck (Donetsk) - 936,0; 6) Zaporoże (Zaporizhzhya) - 762,0; 7) Lwów (Lviv) - 729,0; 8) Krzywy Róg (Kryvyi Rig) - 648,0; 9) Mikołajów (Nikolayiv) - 495,0; 10) Marimpol (Mariupol) - 455,0.

Wegry: 1) Budapeszt (Budapest) - 1735,7; 2) Debreczyn (Debrecen) - 204,9; 3) Miszkolc (Miskolc) - 162,9; 4) Szeged - 161,8; 5) Pecz (Pécs)- 147,7; 6) Gyor (Györ) - 128,6; 7) Nyiregyhaza (Nyíregyháza) - 118,2; 8) Kecskemet (Kecskemét) - 111,9; 9) Székesfehérvar - 99,2; 10) Szombathely $-79,3$.

\section{Bibliografia}

Statystyczne materiały źródłowe:

National Statistical Committee of the Republic of Belarus (2015), Minsk city.

National Institute of Statistics Romanian Statistical Yearbook 1990-2012 (2014), Bucharest.

National Institute of Statistics Romania in Figures (2014), Bucharest.

Regional Statistical Yearbook of Slovakia 2014 (2014), Statistical Office of the Slovak Republic, Bratislava. 
Republic of Bulgaria, National Statistical Institute 2014 (2015), Sofia.

Rocznik Statystyczny Rzeczypospolitej Polskiej (2015), Główny Urząd Statystyczny, Warszawa.

Statistical Yearbook of the Czech Republic 2014 (2014), Czech Statistical Office, Praha.

Statistical Yearbook of Lithuania 2013 (2013), Statistics Lithuania, Vilnius.

Statistical Yearbook of Latvia 2014 (2015), Central Statistical Buremu of Latvia, Riga.

Statistical Yearbook of the Republic of Moldova 2012 (2012), National Buremu of Statistics of the Republic of Moldova, Chişinău.

Statistical Yearbook of Ukraine for 2014 (2015), State Statistics Sernice of Ukraine, Pablishing House „Konsultant” Ltd., Kyiv.

Statistical Yearbook of Hungary 2014 (2015), Hungarian Central Statistical Office, Budapeszt.

\section{Literatura przedmiotu:}

Auerbach F. (1913), Das Gesetz der Bevölkerungskonzentration, „Petermanns Geographische Mitteilungen”, vol. 59, 1.

Biderman E. (1978), Regionotwórcza rola miast - próba ujęcia systemowego, Uniwersytet Adama Mickiewicza, Seria Geografia, t. 8, Poznań.

Domański R. (2000), Zasady geografii społeczno-ekonomicznej, Wydawnictwo Naukowe PWN, Warszawa-Poznań.

Dziewoński K. (1962), Procesy urbanizacyjne we współczesnej Polsce, „Przegląd Geograficzny", t. 34, z. 3.

Eberhardt P., Heřman S. (1975), Koncentracja przestrzenna ludności w aglomeracjach miejskich $w$ wybranych państwach świata, „Przegląd Geograficzny”, t. 47, z. 2.

Golachowski S., Kostrubiec B., Zagożdżon A. (1974), Metody badań geograficznoosadniczych, PWN, Warszawa.

Holzer J. Z., (1999), Demografia, PWE, Warszawa.

Kosiński L. (1967), Geografia ludności, PWN, Warszawa.

Kosiński L. (1966), Obraz demograficzny Europy, OMEGA PWN, Warszawa.

Korcelli P. (2000), Europejski system miast, „Przegląd Geograficzny”, t. 72, z. 4.

Maik W. (1992), Podstawy geografii miast, Wydawnictwo Uniwersytetu Mikołaja Kopernika, Toruń.

Stewart Ch. T. jr. (1958), The Size and Spacing of Cities, "Geographical Review", vol. 48.

Zipf G. K. (1946), The P1P2/D Hypothesis On the Intercity Movement of Persons, "American Sociological Review", vol. 11.

Zipf G. K. (1949), Human behavior and the principle of least effort. An human ecology, Addison-Wesley, Press Inc., Cambridge-Massachusetts. 
Żółtowska J. E. (2000), Układy wielkościowe największych ośrodków miejskich w państwach położonych na pomoście battycko czarnomorskim, „Magazyn Planowania Przestrzennego PRZESTRZEŃ”, Włocławskie Towarzystwo Naukowe, Włocławek, nr 16-2, s. 25-31, 5 tabel, 3 ryciny.

Żółtowska J. E., (2016), Metody zwiqzane z badaniem zjawiska koncentracji przestrzennej osadnictwa i Metody zwiqzane z zastosowaniem modeli grawitacji i potencjału, w: Metodyka geografii osadnictwa. Wybrane modele i narzędzia badań geograficzno-osadniczych oraz możliwości zastosowania ich w planowaniu przestrzennym, Oficyna Wydawnicza Politechniki Warszawskiej, Warszawa.

\section{Adresy internetowe:}

Hungary-Population 2015, 27.11. 2017.

GeoHive Urban (rural division of countries for the years 2015 and 2025) - Biatoruś, 15.01.2016.

GeoHive Urban (rural division of countries for the years 2015 and 2025) - Butgaria, 15.01.2016.

GeoHive Urban (rural division of countries for the years 2015 and 2025) - Republika Czeska, 15.01.2016.

GeoHive Urban (rural division of countries for the years 2015 and 2025) - Estonia, 15.01.2016.

GeoHive Urban (rural division of countries for the years 2015 and 2025) - Mołdawia, 15.01.2016.

GeoHive Urban (rural division of countries for the years 2015 and 2025) - Rumunia, 15.01.2016.

List of cities in the Baltic states by population, 2010-2015, Estonia, 27.11.2017.

List of cities in the Baltic states by population, 2012, 2013, 2015, Litwa, 27.11.2017. List of cities in the Baltic, 2011, 2014, 2015, Łotwa, 27.11.2017.

List of cities and towns in Hungary, Population 2013, Szombathely 2012, 15.01.2016.

\section{Distributions of large urban centers in the countries of the Baltic-Black Sea continental bridge}

\section{Summary}

The purpose of this study was to compare the distributions of large urban centers in twelve countries: Belarus, Bulgaria, Czechia, Estonia, Hungary, Latvia, Lithuania, Moldavia, Poland, Romania, Slovakia, and Ukraine. In order to analyze the research problem identified, two study methods were applied: Zipf's rank-frequency rule and an analysis of the degree of concentration using the Lorentz curve. Firstly, the paper 
presents the issues related to the demographic development of the capital cities in the selected countries considered at five moments in time (1900,1930, 1960, 2000, and around 2015). Then, based on the methodology adopted, a quantified assessment of the role of the biggest city was carried out and presented, along with the relations in magnitude existing between this city and the remaining settlement units analyzed. Countries were divided into those characterized by monocentric and polycentric patterns. The ultimate results of the statistical analysis demonstrated the usefulness of the methodology applied in the study of the distribution and magnitudes of various kinds of settlement units on an arbitrarily defined territory.

Key words: demography of settlements, towns, Baltic-Black Sea continental bridge, Zipf's rule, Lorentz concentration curve 